\title{
PENINGKATAN PENGUASAAN MATERI IPA KONSEP SUHU METODE DEMONSTRASI PADA SISWA SMP NEGERI 8 MAKASSAR
}

\author{
Andi Saddia \\ Universitas Sulawesi Barat \\ Email: andisaddia6@gmail.com
}

\begin{abstract}
Abstrak
Tujuan penelitian ini adalah untuk mengetahui peningkatan penguasaan materi pelajaran Ipa sub konsep Suhu pada siswa SMP Negeri 8 Makassar melalui metode demonstrasi. Penelitian ini merupakan penelitian tindakan yang berbasis kelas (class room research) yang bersifat deskriptif dan bertujuan untuk mengetahui peningkatan penguasaan materi pelajaran Ipa sub konsep Suhu pada siswa SMP Negeri 8 Makassar melalui metode demonstrasi. Subyek penelitian ini adalah siswa kelas VII SMP Negeri 8 Makassar, yaitu kelas VII B dengan jumlah siswa sebanyak 36 orang yang terdiri dari 26 siswa perempuan dan 10 laki-laki. Dalam penelitian ini juga dilibatkan 2 orang guru mata pelajaran Ipa sebagai partisipan dan teman diskusi. Penelitian ini dilaksanakan dalam 2 siklus (siklus I dan siklus II). Terjadi peningkatan tingkat pemahaman materi pelajaran Ipa siswa kelas VII B SMP Negeri 8 Makassar pada sub konsep Suhu melalui metode demonstrasi dari kategori tidak tuntas belajar klasikal dan nilai rata-rata 68,07 setelah pelaksanaan tindakan siklus I menjadi kategori tuntas belajar klasikal dan nilai rata-rata 78,41 setelah pelaksanaan siklus II.
\end{abstract}

Kata Kunci: Penelitian Tindakan Kelas, Peningkatan Penguasaan Materi, Metode Demontrasi

\begin{abstract}
The purpose of this study was to determine the increase in mastery of the science subject matter of the temperature sub-concept in the students of SMP Negeri 8 Makassar through the demonstration method. This research is a class-based action research (class room research) which is descriptive in nature and aims to determine the increase in mastery of the subject matter of Science, the sub-concept of Temperature in students of SMP Negeri 8 Makassar through the demonstration method. The subjects of this study were students of class VII SMP Negeri 8 Makassar, namely class VII B with a total of 36 students consisting of 26 female students and 10 male students. In this study, 2 science teachers were also involved as participants and discussion partners. This research was conducted in 2 cycles (cycle I and cycle II). There was an increase in the level of understanding of the science subject matter of class VII B SMP Negeri 8 Makassar on the temperature sub concept through the demonstration method from the category of incomplete classical learning and the average value of 68.07 after the implementation of the first cycle of action to the category of complete classical learning and the average score. an average of 78.41 after the implementation of the second cycle.
\end{abstract}

Keywords: Classroom Action Research, Improvement of material mastery, demonstration method.

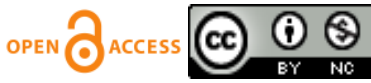




\section{PENDAHULUAN}

Dewasa ini Ilmu Pengetahuan dan Teknologi mengalami perkembangan dengan sangat pesat dan pengaruhnya terhadap berbagai aspek kehidupan manusia sangat besar, termasuk pada bidang pendidikan . Ilmu pengetahuan dan teknologi merupakan dua faktor yang sangat berperan dalam mempercepat proses perubahan dalam masyarakat menuju keadaan yang lebih baik. Dengan demikian ,ilmu pengetahuan dan teknologi merupakan variabel utama dalam menjalankan pembangunan bangsa yang bersangkutan, termasuk di Indonesia.

Peranan matematika dan Ilmu Pengetahuan Alam (IPA), khususnya IPA dalam perkembangan ilmu pengetahuan dan teknologi sangat mendukung pembangunan nasional. Oleh karena itu, pengajaran Ipa pada setiap jenjang pendidikan diharapkan dapat memberikan hasil sesuai dengan yang diharapkan. Namun demikian, kenyataan menunjukkan bahwa penguasaan materi yang tercermin dari prestasi belajar Ipa siswa di sekolah pada semua jenjang pendidikan masih relatif lebih rendah dibandingkan dengan mata pelajaran lainnya. Hal ini dipertegas dengan pernyataan Djojonegoro (1994:76) selaku Menteri Pendidikan Nasional Republik Indonesia saat itu bahwa: Tingkat daya serap siswa tingkat SMP dan SMA terhadap materi kurikulum matematika dan IPA hingga kini belum mencapai separuh dari tuntutan kurikulum.Khusus untuk mata pelajaran Ipa, pernyataan tersebut didukung oleh data hasil belajar Ipa di SMP dan SMA beberapa tahun ini yang menunjukkan angka relatif rendah [1].

Hal tersebut menjadi pekerjaan rumah bagi instansi terkait, khususnya guru mata pelajaran Ipa untuk mencari alternatif pemecahannya. Berbagai cara dan upaya yang dapat dilakukan untuk meningkatkan penguasaan materi pelajaran Ipa. Salah satu diantaranya adalah dengan menerapkan metode mengajar yang tepat, yang bertujuan agar ketuntasan belajar dapat dicapai, sehingga tujuan pembelajaran Ipa yang telah dirumuskan dapat tercapai secara maksimal.

Pengalaman penulis sebagai pengajar pada SMP Negeri 8 Makassar menunjukkan bahwa sampai saat ini metode mengajar yang diterapkan guru dalam setiap proses pembelajaran masih dirasakan belum memberikan hasil yang maksimal. Pada hal dalam proses pembelajaran, penggunaan metode mengajar sangat penting dalam menunjang keberhasilan pengajaran untuk mencapai tujuan pembelajaran secara efektif dan efisien. Oleh karena itu, metode mengajar yang digunakan diharapkan dapat meningkatkan penguasaan siswa di satu sisi dan memperkecil kesulitan belajar siswa dalam memahami materi pelajaran di sisi lainnya. Hal ini sesuai dengan pernyataan Nasution (1990:13) bahwa:Penyampaian materi pelajaran yang telah dirumuskan, perlu mempertimbangkan metode mengajar yang tepat digunakan dengan mempertimbangkan kegiatan yang telah ditetapkan dan tujuan pembelajaran yang akan dicapai.[2]

Untuk keperluan tersebut, maka ada beberapa macam metode mengajar yang dapat digunakan yang merupakan sarana untuk membantu siswa dalam memperoleh pengetahuan (kognitif), sikap (afektif), dan keterampilan (psikomotor) menuju kepada perubahan tingkah laku. Menurut Engkoswara (1988:11): Beberapa metode mengajar yang dimaksud antara lain adalah: metode ceramah, tanya jawab, diskusi, pemberian tugas, eksperimen, bekerja dalam kelompok, resitasi, proyek, karya wisata, problem solving, demonstrasi dan lain-lain. [3].

Dengan mempertimbangkan materi dalam mata pelajaran Ipa yang perlu ditunjang dengan praktikum serta kondisi kelas di 
Indonesia, maka salah satu metode mengajar yang dianggap cocok untuk diterapkan dalam proses pembelajaran adalah metode demonstrasi. Dari segi materi penerapan metode demonstrasi dalam proses pembelajaran dalam menunjang pengajaran Ipa tidak terlepas dari hakikat fisika sebagai ilmu yang lahir serta berkembang atas dasar observasi dan eksperimen. Selanjutnya dari kondisi kelas, masih banyaknya anggota siswa dalam situasi kelas mengakibatkan pelaksanaan metode eksperimen kadang tidak bisa dilaksanakan karena keterbatasan alat dan bahan. Atas dasar tersebut, agar praktikum tetap dapat dilaksanakan dalam kondisi kelas yang cukup padat, maka pemilihan metode demonstrasi dalam pembelajaran Ipa dianggap cukup tepat.

Penerapan metode demonstrasi dalam pembelajaran Ipa, khususnya melalui belajar tuntas diharapkan dapat meningkatkan penguasaan siswa terhadap materi yang diajarkan. Hal ini tidak terlepas dari kelebihan yang dimiliki oleh metode demonstrasi. Menurut Roestiyah (1989:54) bahwa: Beberapa kelebihan penerapan metode demonstrasi dalam proses pembelajaran adalah: (1) membantu siswa memahami dengan jelas jalannya suatu proses; (2) memudahkan berbagai jenis penjelasan sebab penggunaan bahasa lebih terbatas; (3) menghilangkan verbalisme; dan (4) memberikan keterampilan tertentu". Selanjutnya, dari beberapa konsep dalam mata pelajaran Ipa yang dapat diajarkan dengan penerapan metode demonstrasi, salah satu diantaranya adalah sub konsep Suhu. [4]

Berdasarkan uraian diatas , maka penulis merancang sebuah penelitian yang akan dilakukan pada SMP Negeri 8 Makassar untuk meningkatkan penguasaan siswa pada materi Ipa, khususnya pada sub konsep Suhu melalui belajar tuntas dengan penerapan metode demonstrasi.Alasan pemilihan SMP Negeri 8 Makassar sebagai lokasi penelitian didasarkan bahwa peneliti adalah guru tetap yang mengajar disekolah tersebut, dan hasil pengalaman yang menunjukkan bahwa nilai ulangan harian siswa masih rendah sehingga menyebabkan pencapaian ketuntasan belajar tidak sesuai dengan yang diharapkan. Untuk merealisasikan maksud tersebut, mengajukan judul penelitian: "Peningkatan Penguasaan Materi Pelajaran Ipa sub konsep Suhu Melalui Metode Demonstrasi Siswa SMP Negeri 8 makassar".

\section{METODE PENELITIAN}

Penelitian ini merupakan penelitian tindakan yang berbasis kelas (classroom research) yang bersifat deskriptif dan bertujuan untuk mengetahui peningkatan penguasaan materi pelajaran Ipa sub konsep Suhu pada siswa SMP Negeri 8 Makassar melalui metode demonstrasi. Subjek penelitian ini adalah siswa kelas VII SMP Negeri 8 Makassar, yaitu kelas VII B dengan jumlah siswa sebanyak 36 orang yang terdiri dari 26 siswa perempuan dan 10 laki-laki. Dalam penelitian ini juga dilibatkan 2 orang guru mata pelajaran Ipa sebagai partisipan dan teman diskusi. Penelitian ini dilaksanakan dalam 2 siklus (siklus I dan siklus II), dimana antara pelaksanaan tindakan siklus I dengan pelaksanaan tindakan siklus II merupakan rangkaian kegiatan yang saling berkaitan. Dalam artian bahwa, pelaksanaan siklus II merupakan kelanjutan dan perbaikan dari pelaksanaan tindakan siklus I. Prosedur tindakan yang dilakukan mengikuti model Kemmis and MC.Taggart yang terdiri atas 5 komponen, yaitu: permasalahan, perencanaan tindakan, observasi, dan refleksi. 
Siklus I

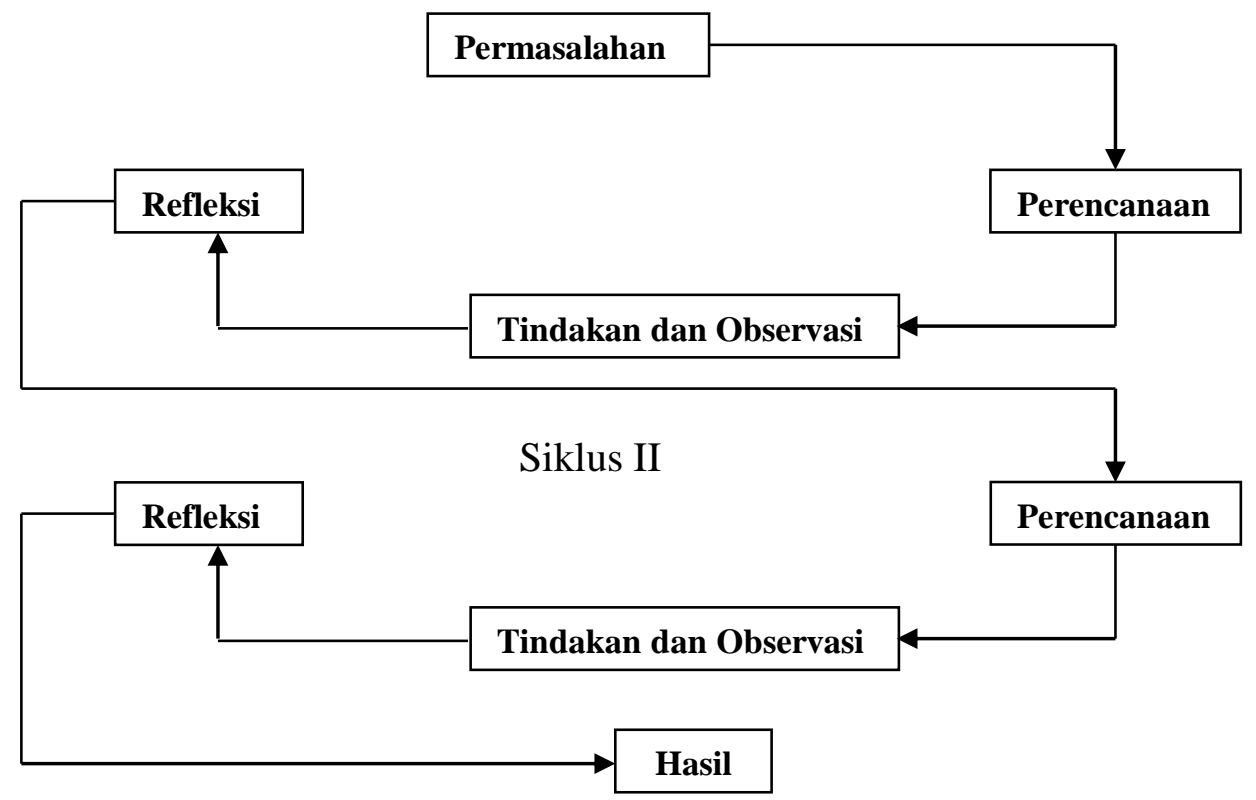

Gambar 1. Skema Prosedur Pelaksanaan Tindakan

\section{HASIL DAN DISKUSI}

\section{Hasil}

Pelaksanaan tindakan siklus I

Pada pelaksanaan tindakan siklus I, proses pembelajaran dilakukan dengan menggunakan metode demontrasi. Sesuai dengan skenario pembelajaran yang telah disusun, pelaksanaan demonstrasi dilakukan sendiri oleh guru tanpa melibatkan siswa. Dalam artian bahwa siswa hanya mengamati proses yang terjadi dalam pelaksanaan demontrasi, dan mencatat penjelasan yang diberikan oleh guru.

Pada setiap akhir pelaksanaan demontrasi,siswa diminta untuk mengajukan pertanyaan-pertanyaan menyangkut materi yang didemontrasikan. Selanjutnya, siswa menyimpulkan hasil pelaksanaan demontrasi.
Hasil Analisis Penguasaan Materi Siklus I

Nilai hasil pemberian tes yang menujukkan tingkat peguasaan materi pelajaran Ipa pada sub konsep Suhu siswa kelas VII B SMP Negeri 8 Makassar setelah pelaksanaan tindakan siklus I melalui metode demonstrasi selengkapnya disajikan pada lampiran 2 .

Dari hasil analisis deskriptif diperoleh rangkuman nilai statistic tingkat penguasaan materi pelajaran Ipa pada sub konsep Suhu kelas VII B SMP Negeri 8 Makassar setelah pelaksanaan siklus I melalui metode demonstrasi seperti ditunjukkan pada Tabel I:

Tabel 1. Hasil Analisis Deskriptif Tingkat Penguasaan Materi Pelajaran Ipa pada sub konsep Suhu Siswa Kelas VII B

SMP Negeri 8 Makassar Setelah Pelaksanaan Tindakan Siklus I Melalui Metode Demonstarsi

\begin{tabular}{l|l} 
Statistik & Nilai Statistik
\end{tabular}




\begin{tabular}{|l|c|}
\hline Ukuran sampel & 36 \\
\hline Nilai tertinggi & 85 \\
\hline Nilai terendah & 50 \\
\hline Rentang nilai & 35 \\
\hline Nilai rata-rata & 68,07 \\
\hline Standar deviasi & 8,87 \\
\hline
\end{tabular}

Data pada Tabel 1 menunjukkan bahwa, dari 36 siswa kelas I SMP Negeri 8 Makassar yang menjadi obyek penelitian, nilai tertinggi yang diperoleh yang menunjukkan tingkat penguasaan materi pelajaran Ipa pada sub konsep Suhu siswa kelas VII B SMP Negeri 8 Makassar setelah pelaksanaan siklus pertama melalui metode demonstarsi adalah 85; nilai terendah 50; skor rata-rata 68,07 dan stsndar deviasi 8,87 .

Dari keseluruhan nilai yang diperoleh siswa, jika dokelompokkan dalam dua kategori, yaitu kategori tuntas belajar dan kategori tidak tuntas belajar, maka distribusi frekuensi, persentase, serta kategori tingkat penguasaan materi pelajaran Ipa pada sub konsep Suhu siswa kelas VII B SMP Negeri 8 Makassar setelah pelaksanaan siklus I melalui metode demonstrasi ditunjukkan pada table 2 .

Tabel 2. Distribusi Frekuensi, Persentase, serta Kategori Tingkat Penguasaan Materi Pelajaran Ipa pada sub konsep Suhu Siswa

Kelas VII B SMP Negeri 8 Makassar Setelah Pelaksanaan Tindakan Siklus I Melalui Metode Demonstrasi

\begin{tabular}{|l|c|c|c|}
\hline $\begin{array}{l}\text { Interva } \\
\text { 1 Nilai }\end{array}$ & $\begin{array}{c}\text { Kategor } \\
\mathrm{i}\end{array}$ & $\begin{array}{c}\text { Frekuens } \\
\mathrm{i}\end{array}$ & $\begin{array}{c}\text { Persentas } \\
\mathrm{e}\end{array}$ \\
\hline $\begin{array}{l}\text { 65\% ke } \\
\text { atas }\end{array}$ & $\begin{array}{c}\text { Tuntas } \\
\text { belajar }\end{array}$ & 24 & 68,18 \\
\hline $\begin{array}{l}\text { Di } \\
\text { bawah }\end{array}$ & $\begin{array}{c}\text { Tidak } \\
\text { tuntas }\end{array}$ & 12 & 31,82 \\
\hline
\end{tabular}

\begin{tabular}{|l|l|l|l|}
\hline $65 \%$ & belajar & & \\
\hline Jumlah & & 36 & 100 \\
\hline
\end{tabular}

Data pada Tabel 2 menujukkan bahwa dari 36 siswa kelas VII B SMP Negeri 8 Makassar yang menjadi obyek penelitian, $24(68,18 \%)$ yang memiliki tingkat penguasaan materi pelajaran Ipa pada sub konsep Suhu sertelah pelaksanaan tindakan siklus I melalui metode demonstrasi yang dikategorikan tuntas belajar dan 12 $(31,82 \%)$ yang dikategorikan tidak tuntas belajar.

\section{Hasil Refleksi Siklus I}

Berdasarkan hasil observasi berupa pemberian tes setelah pelaksanaan tindakan siklus I dan pengamatan perilaku siswa selama pelaksanaan tindakan siklus I melalui metode demonstrasi, terlihat bahwa tingkat penguasaan materi pelajaran Ipa siswa kelas VII B SMP Negeri 8 Makassar pada sub konsep Suhu dikategorikan tidak tuntas secara klasikal, dengan nilai rata-rata yang diperoleh siswa 68,07 dan persentase 68,18 \%.Selain itu,berdasarkan observasi di kelas masih ditemukan perilaku siswa yang dapat mengganggu pelaksanaan pembelajaran, serta masih rendahnya aktivitas siswa dalam proses pembelajaran.

Hasil refleksi tersebut menjadi dasar acuan dilanjutkan pelaksanaan tindakan ke siklus II dengan mengupayakan perbaikan dalam proses pembelajaran,diantaranya mengikutsertakan siswa dalam pelaksanaan demontrasi dan menggunakan alat peraga.

Pelakasanaan Tindakan Siklus II

Berdasarkan hasil refleksi pelaksanaan tindakan siklus I, maka dalam proses pembelajaran pelaksanaan demontrasi dilakukan oleh guru dengan melibatkan siswa. Hal ini dilakukan untuk meningkatkan keaktifan dan keterlibatan siswa dalam pelaksanan proses 
pembelajaran. Selain itu, untuk memperjelas materi yang diajarkan dengan pelaksanaan praktikum, pada pelaksanaan pembelajaran juga digunakan alat peraga atau alat bantu mengajar.

Seperti halnya pada siklus I, pada setiap akhir pelaksanaan demonstrasi, siswa diminta untuk mengajukan pertanyaanpertanyaan menyangkut materi yang didemonstrasikan. Selanjtnya, siswa menyimpulkan hasil pelaksanaan demonstrasi.

Hasil Analisis Penguasaan Materi Siklus II

Nilai hasil pemberian tes yang menunjukkan tingkat penguasaan materi pelajaran Ipa pada sub konsep Suhu siswa kelas VII B SMP Negeri 8 Makassar setelah pelaksanaan tindakan siklus II melalui metode demonstrasi selengkapnya disajikan pada lampiran 2.

Dari hasil analisis deskriptif diperoleh rangkuman nilai statistic tingkat penguasaan materi pelajaran Ipa pada sub konsep Suhu siswa kelas VII B SMP Negeri 8 Makassar setelah pelaksanaan tindakan siklus II melalui metode demonstrasi seperti ditunjukkan pada Tabel 3 di bawah ini:

Tabel 3. Hasil Analisis Deskriptif Tingkat Penguasaan Materi Pelajaran Ipa pada Sub Konsep Suhu Siswa Kelas VII B SMP Negeri 8 Makassar setelah Pelaksanaan Tindakan Siklus II Melalui Metode Demonstrasi.

\begin{tabular}{|l|c|}
\hline \multicolumn{1}{|c|}{ Statistik } & Nilai statistik \\
\hline Ukuran sampel & 36 \\
\hline Nilai tertinggi & 95 \\
\hline Nilai terendah & 60 \\
\hline Rentang nilai & 35 \\
\hline Nilai rata-rata & 78,41 \\
\hline Standar deviasi & 10,27 \\
\hline
\end{tabular}

Data pada table 3 menunjukkan bahwa, dari 36 siswa kelas VII SMP Negeri 8
Makassar yang menjadi obyek penelitian, nilai tertinggi yang diperoleh yang menunjukkan tingkat penguasaan materi pelajaran Ipa pada sub konsep suhu siswa kelas VII B SMP Negeri 8 Makassar setelah pelaksanaan tindakan siklus II melalui demonstrasi adalah 95, nilai terendah 60 , skor rata-rata 78,41 dan standar deviasi 10,27.

Dari keseluruhan nilai yang diperoleh siswa, jika dikelompokkan dalam dua kategori, yaitu kategori tuntas belajar dan kategori tidak tuntas belajar, maka distribusi frekuensi,persentase,serta kategori tingkat penguasaan materi pelajaran Ipa pada pokok bahasa suhu siswa kelas VII B SMP Negeri 8 Makassar setelah pelaksanaan tindakan siklus II melalui metode demonstrasi ditunjukkan pada Tabel 4 di bawah ini.

Tabel 4.Distribusi

Frekuensi,Persentase,serta Kategori Tingkat Penguasaan Materi Pelajaran Ipa pada sub konsep Suhu Siswa Kelas VIIB SMP Negeri 8 Makassar Setelah Pelaksanaan Tindakan Siklus II Melalui Metode emonstrasi.

\begin{tabular}{|l|l|c|c|}
\hline $\begin{array}{l}\text { Interva } \\
\text { 1 Nilai }\end{array}$ & $\begin{array}{c}\text { Kategor } \\
\mathrm{i}\end{array}$ & $\begin{array}{c}\text { Frekuens } \\
\mathrm{i}\end{array}$ & $\begin{array}{c}\text { Persentas } \\
\mathrm{e}\end{array}$ \\
\hline $\begin{array}{l}\text { 65\% ke } \\
\text { atas }\end{array}$ & $\begin{array}{l}\text { Tuntas } \\
\text { belajar }\end{array}$ & 31 & 88,64 \\
\hline $\begin{array}{l}\text { Di } \\
\text { bawah } \\
65 \%\end{array}$ & $\begin{array}{l}\text { Tidak } \\
\text { tuntas } \\
\text { belajar }\end{array}$ & 5 & 11,36 \\
\hline Jumlah & & 35 & 100 \\
\hline
\end{tabular}

Data pada Tabel 4 menunjukkan bahwa dari 36 siswa kelas VIIB SMP Negeri 8 Makassar yang menjadi objek penelitian, $31(88,64 \%)$ yang memiliki tingkat penguasaan materi pelajaran Ipa pada sub konsep Suhu setelah pelaksanaan tindakan siklus II melalui metode demonstrasi yang 
dikategorikan tuntas belajar dan $(11,36 \%)$ yang dikategorikan tidak tuntas belajar.

\section{Hasil Refleksi Siklus II}

Berdasarkan hasil observasi berupa pemberian tes setelah pelaksanaan tindakan siklus II dan pengamatan perilaku siswa selama pelaksanaan tindakan siklus II melalui metode demonstrasi,terlihat bahwa tingkat penguasaan materi pelajaran Ipa siswa kelas VII B SMP Negeri 8 Makassar pada sub konsep Suhu dikategorikan tuntas secara klasikal,dengan nilai rata-rata yang diperoleh siswa 78,41 dan persentase $88,64 \%$.Selain itu,dari hasil observasi terlihat bahwa keterlibatan aktivitas siswa dalam proses pembelajaran mengalami peningkatan, demikian pula sebaliknya.

Hasil yang diperoleh dari pelaksanaan tindakan siklus II merupakan hasil akhir dari pelaksanaan penelitian yang telah dilakukan melalui metode demonstrasi, yang hasilnya menjadi rekomendasi dalam pengajaran bidang studi Ipa.

\section{Pembahasan}

Berdasarkan hasil analisis data yang telah diuraikan diatas, maka secara deskriptif hasil penelitian tindakan ini mengungkapkan adanya perbedaan tingkat penguasaan materi pelajaran Ipa siswa kelas VII B SMP Negeri 8 Makassar melalui metode demonstrasi antara setelah pelaksanaan tindakan siklus I dengan setelah pelaksanaan tindakan siklus II.

Hasil observasi dan refleksi setelah pelaksanaan tindakan siklus I terlihat bahwa secara umum tingkat penguasaan materi pelajaran Ipa siswa kelas VII B SMP Negeri 8 Makassar melalui metode demonstrasi tidak tuntas belajar secara klasikal dengan nilai rata-rata 68,07. Disamping itu, dari hasil pengamatan perilaku siswa selama berlangsungnya proses belajar mengajar pada pelaksanaan tindakan siklus I menunjukkan rata-rata persentase perilaku positif siswa berdasarkan indikator yang diamati masih rendah, sebaliknya rata-rata persentase perilaku rendah masih tinggi.

Berdasarkan hasil observasi dan refleksi setelah pelaksanaan tindakan siklus II terlihat secara umum tingkat penguasaan materi pelajaran Ipa siswa kelas VII b SMP Negeri 8 Makassar melalui metode demonstrasi mengalami peningkatan dari kategori tidak tuntas belajar secara klasikal menjadi kategori tuntas belajar secara klasikal. Selain itu, nilai rata-rata yang diperoleh mengalami peningkatan dari 68,07 menjadi 78,41 .

Untuk lebih jelasnya, perbandingan tingkat penguasaan umum tingkat penguasaan materi pelajaran Ipa siswa kelas VII B SMP Negeri 8 Makassar melalui metode demonstrasi berdasarkan kategori ketuntasan belajar setelah pelaksanaan tindakan siklus I dan Siklus II ditunjukkan dalam bentuk histogram pada gambar 2 di bawah ini :

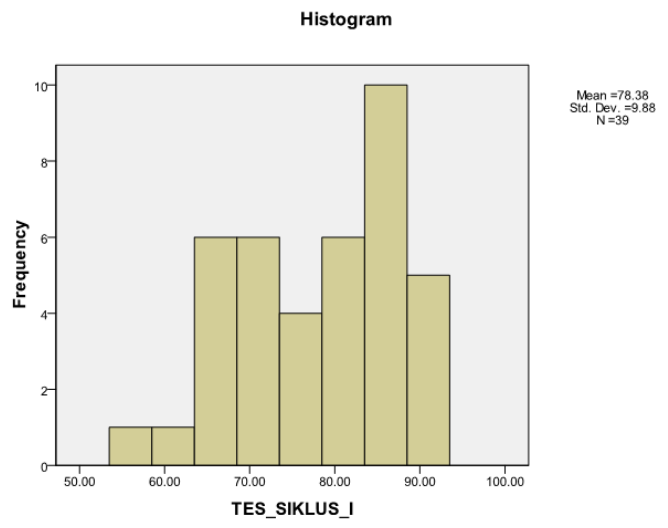

Gambar 2. Histogram yang menunjukkan kategori tingkat penguasaan terhadap materI Pelajaran Ipa siswa kelas VII B SMP Negeri 8 Makassar setelah pelaksanaan Tindakan siklus I dan siklus II.

Selanjutnya berdasarkan hasil pengamatan perilaku siswa selama berlangsungnya proses belajar mengajar pada pelaksanaan 
tindakan siklus II menunjukkan peningkatan rata-rata persentase perilaku siswa berdasarkan perilaku positif yang diamati. Misalnya : (1) Rata-rata persentase kehadiran siswa dari 95,45\% pada pelaksanaan tindakan siklus I meningkat menjadi 97,73 \% pada pelaksanaan tindakan siklus II,( 2). 35,51 $\%$ bertanya saat guru menjelaskan meski belum diberi kesempatan meningkat menjadi 36,36, (3). 50,00\% bertanya pada saat diberi kesemapatn meningkat menjadi $67,05 \%$, (4) $31,82 \%$ memberi tanggapan terhadap materi yang dijelaskan oleh guru meningkat menjadi $37,50 \%$, (5) $34,09 \%$ memberi jawaban jika guru bertanya meningkat menjadi $43,18 \%$, (6) $59,85 \%$ memperhatikan penjelasan materi yang diberikan guru meningkat 69,32 \%, (7) $61,36 \%$ mencatat materi pelajaran yang diberikan guru meningkat menjadi 71,59 $\%$,(8) $25,00 \%$ menjawab pertanyaan yang diajukan siswa lain sebelum dijawab guru meningkat menjadi $29,55 \%$, (9) 65,91\% mengerjakan tugas-tugas yang diberikan guru meningkat menjadi $75,00 \%$, (10) $95,45 \%$ mengikuti pelaksanaan demonstrasi yang dilakukan di Laboratorium meningkat menjadi 97,73\%, (11) $0 \%$ ikut melakukan pengamatan dalam pelaksanaan demonstrasi meningkat menjadi $76,14 \%$, (12) $59,09 \%$ berdiskusi dengan teman tentang materi yang dibahas guru meningkat menjadi $70,45 \%$ dan (13) $25,00 \%$ mengacungkan tangan meningkat menjadi $30,68 \%$.

Dari hasil observasi juga terungkap bahwa terjadi penurunan rata-rata persentase perilaku siswa berdasarkan perilaku negative yang diamati. Misalnya : (1) ratarata persentase siswa yang pindah-pindah dari $15,155 \%$ pada pelaksanaan tindakan siklus I menurun menjadi $7,95 \%$ pada pelaksanaan tindakan siklus II, (2) 9,09\% memukul-mukul meja atau bercerita dengan temannya menurun menjadi 5,68 $\%$, (3) $6,06 \%$ makan minum dalam ruangan menurun menjadi $3,41 \%$ dan (4)
$6,82 \%$ keluar masuk ruangan menurun menjadi $3,41 \%$.

Berdasrkan uraian pembahasan di tas terlihat bahwa terjadi peningkatan tingkat penguasaan terhadap materi pelajaran Ipa, khususnya pada sub konsep Suhu siswa kelas VII 8 SMP Negeri 8 Makassar, setelah dilaksanakannya proses belajar mengajar melalui metode demonstarsi. Hal ini ditandai dengan adanya peningkatan kategori tingkat penguasaan dan nilai ratarata yang diperoleh siswa dari hasil pemberian tes tertulis. Sedangkan dari hasil pengamatan langsung, terjadi peningkatan rata-rata persentase perilaku positif disatu pihak dan penurunan perilaku negative dipihak lainnya yang mengindikasikan meningkatkan perhatian,minat,dan motivasi terhadap materi pelajaran.

Temuan dalam penelitian ini mendukung teori yang telah dikemukakan sebelumnya bahwa dengan penggunaan metode demonstrasi keuntungan yang dapat diperoleh adalah siswa dapat lebih terpusatkan pada pelajaran yang sedang diberikan dan kesalahan-kesalahan yang terjadi bila pelajaran itu diceramahkan dapat diatasi melalui pengamatan dan contoh yang kongkrit. Sehingga kesan yang diterima siswa lebih mendalam dan tinggal lebih lama pada jiwanya. Akibatnya selanjutnya adalah memberikan motivasi yang kuat untuk siswa agar lebih giat belajar (Roestiyah, 1998). [5]

\section{SIMPULAN DAN SARAN}

Simpulan

Berdasarkan hasil analisis data dan pembahasan, maka dapat disimpulkan bahwa:

1. Secara kuantitatif, terjadi peningkatan tingkat pemahaman materi pelajaran Ipa siswa kelas VII B SMP Negeri 8 Makassar pada sub konsep Suhu melalui metode demonstrasi dari 
kategori tidak tuntas belajar klasikal dan nilai rata-rata 68,07 setelah pelaksanaan tindakan siklus I menjadi kategori tuntas belajar klasikal dan nilai rata-rata 78,41 setelah pelaksanaan siklus II.

2. Secara kualitatif, terjadi peningkatan rata-rata persentase siswa kelas VII B SMP Negeri 8 Makassar yang melakukan perilaku positif dan terjadinya penurunan rata-rata persentase perilaku negatif dalam setiap pelaksanaan proses belajar mengajar pada pelaksanaan tindakan setiap siklus yang mengindikasikan makin meningkatkan perhatian, minat, dan motivasi siswa terhadap materi pelajaran yang diberikan oleh guru.

\section{Saran}

Berdasarkan kesimpulan hasil penelitian yang telah dikemukakan di atas, maka beberapa saran yang dapat penulis kemukakan, di antaranya adalah sebagai berikut:

1. Kepada guru mata pelajaran Ipa pada umumnya dan yang mengajar di siswa kelas VII B SMP Negeri 8 Makassar pada khususnya agar dalam proses belajar mengajar dapat menerapkan atau menggunakan metode demonstrasi karena dapat meningkatkan penguasaan dan hasil belajar siswa terhadap materi pelajaran yang dijelaskan oleh guru.

2. Diharapkan juga kepada semua guru maka pelajaran IPA untuk sedapat mungkin menguasai berbagai metode mengajar dan alternative strategi mengajar lainnya, agar dalam proses pembelajaran tidak hanya menggunakan satu jenis metode atau strategi mengajar yang dapat menyebabkan proses pembelajaran yang dilakukan bersifat monoton dan membesankan siswa.

3. Kepada peneliti selanjutnya, kiranya dapat mengadakan penelitian lanjutan untuk memperkuat dan mengembangkan hasil penelitian ini dengan menambahkan siklus tindakan dari dua menjadi tiga siklus.

\section{DAFTAR PUSTAKA}

[1] Djojonegoro (1994). Mendikbud Wardiman Djojonegoro sendiri, Departemen Pendidikan dan Kebudayaan

[2] Nasution, S. 1990. Asas-asas Kurikulum. Bandung: Jemmars.

[3] Engkoswara, (1987), Dasar-dasar Administrasi Pendidikan Jakarta • Dirjen Dikti Depdikbud Rl.

[4] Roestiyah (1989). Strategi Belajar Mengajar. Jakarta: PT Rineka Cipta

[5] Roestiyah (1998). Strategi Belajar Mengajar. Jakarta: PT Rineka Cipta 